\title{
FISHERMEN ALLEVIATION POVERTY MODEL IN THE NORTH COASTAL EAST JAVA
}

\author{
Roziana Ainul Hidayati dan Mu'minatus Sholichah \\ Fakultas Ekonomi Universitas Muhammadiyah Gresik \\ Jalan Sumatra 101 GKB Gresik, Jawa Timur, Indonesia, Telepon. +62-031-3951414
}

Diterima 4 Mei 2011/Disetujui 25 September 2011

\begin{abstract}
Poverty is a multidimensional problem that the approach to eradicate poverty must also be multidimensional. The study aims to formulate a model of poverty alleviation in coastal fishing in the North Coast of East Java. Grounded research approach used to determine the causes, impacts and implications of poverty fishermen. The results showed that the main cause of poverty that occurred in the three districts in East Java's north coast is different from one another. In Gresik district, the major cause of poverty is law enforcements that do not support fishermen and overfishing. While Lamongan more due to low fish prices and capital problems. While in Tuban fishermen due to limited infrastructure and lazy and extravagant lifestyle of the fishermen. These differences lead to different coping strategies so that later can form a concept model of poverty alleviation North Coast fishermen in East Java.
\end{abstract}

Keywords: alleviation poverty, poverty fishermen, coastal communities, structural poverty

\begin{abstract}
Abstrak: Kemiskinan merupakan masalah multidimensi sehingga pendekatan untuk memberantas kemiskinan juga harus multidimensi. Penelitian ini bertujuan merumuskan model pengentasan kemiskinan nelayan pesisir di Pantai Utara Jawa Timur. Pendekatan penelitian ini adalah penelitian grounded untuk menentukan penyebab, dampak dan implikasi dari kemiskinan nelayan. Hasilnya menunjukkan bahwa penyebab utama dari kemiskinan yang terjadi di tiga kabupaten di pantai utara Jawa Timur berbeda beda. Di kabupaten Gresik, penyebab utama kemiskinan adalah penegakan hukum yang tidak mendukung nelayan dan adanya penangkapan ikan yang berlebihan. Sementara itu kemiskinan di Lamongan disebabkan harga ikan yang rendah dan persoalan modal. Di Tuban, kemiskinan disebabkan keterbatasan infrastruktur, gaya hidup mewah dan malas dari nelayan. Perbedaan-perbedaan tersebut menyebabkan strategi penanganan yang berbeda sehingga nantinya bisa membentuk sebuah model konsep pengentasan kemiskinan nelayan pantai utara di Jawa Timur.
\end{abstract}

Kata kunci: pengentasan kemiskinan, kemiskinan nelayan, komunitas nelayan pesisir

\section{INTRODUCTION}

East Java Province is one of the provinces in Indonesia which have coastal areas. The region has 229 islands with a length of $2.833,85 \mathrm{~km}$ coastline. Along the northern coastal region of East Java, there is a potential natural resources that have not managed optimally. But, the other hand there is also the activity of natural resource use that have a tendency to be exploita- tive and sectoral. As the largest province in Java, East Java Province has a relatively high economic activity so as to provide a real impact in improving economic growth, including the increasing level of welfare. However, the economic growth that occurred was not evenly felt by people in the northern coastal region. One indicator is still the presence of slums in some parts of coastal areas that reflect the persistence of pockets of poverty.

Coastal Villages is one of the coastal region 
was a very marginal out, therefore the coastal villages potentially become pockets of poverty. Poverty and socio-economic pressures faced by the fishing households in coastal villages stems from complex factors are interlinked.

Fishermen themselves are generally composed of poor fishery households who catch fish without a boat, using a boat without a motor and outboard motor boats. With this scale, the household is only able to catch fish in the area near the beach. Various efforts to reduce poverty have been carried out, but the government does not have a clear concept, so the handling is still to be partial and not integrated. As a result, poverty rates can not be reduced significantly. And even with the existence of poverty reduction programs, even increasing the number of poor fishermen. The problem of poverty is as if it is a matter of manifest and latent. If left unchecked, will be reproduced again by future generations of coastal fishermen. Clearly and obviously due to poverty all the fishermen suffer and feel the consequences. Of course, all will bear the losses and expenses of this poverty. For it is necessary to develop a model of poverty alleviation development of fishermen in coastal areas of East Java in the hope north coastal obtain a sustainable livelihood.

Therefore, this research is very important and urgently needed in order to see the real problem the real picture of poverty fishermen in coastal areas of East Java and the impact or implications accepted by the fishermen on the coast of East Java and to find ways/methods/ strategies used by fishermen in reducing and preventing poverty. Formula for estimating the poverty model that can be developed to provide opportunities to build and implement economic, sustainable welfare of fishermen.

Many studies have been conducted on the phenomenon of poverty of coastal communities, one conducted by Smith (1979). According to Smith (1979) who conducted the study of fisheries development in various Asian countries and Anderson (1979) did so in countries of Europe and North America came to the conclusion that stiffness fisheries assets (fixity and rigidity of fishing assets) is the main reason why fishing equipment living or struggling with poverty and nothing seems their efforts to get out of poverty. Stiffness of these assets is because the nature of the fisheries assets in such a way that it is difficult to be liquidated or converted form and function to be used for other purposes. As a result, when the low productivity of these assets, fishermen are not able to change enable or liquidate those assets. Therefore, despite low productivity, fishermen continue to do the actual fishing operations is no longer economically efficient.

Poverty fishing in waters of the north coast of East Java by Wahyudi and Muzni (2007) caused more structural aspects and cultural aspects. Structural poverty itself according Kusnadi (2006) is poverty caused by the influence of external factors or variables beyond the individual. These variables are the socioeconomic structure of society, the availability of incentives or disincentives to development, availability of construction facilities, availability of technology, and availability of resources, especially natural resource development. The relationship between these variables and poverty are generally reversed. This means that the higher the intensity, volume and quality of these variables, the diminishing poverty. Especially for the social structure of economic variables, its relationship with poverty more difficult to determine. What is clear is that the social and economic conditions of society that occurred in the vicinity or in the scope of the fishermen to determine their poverty and welfare. While the cultural poverty is poverty due to the inherent variables, inherent, and a certain lifestyle. As a result it is difficult to concerned individuals out of poverty because they do not realize it or not known by the individuals concerned. Variables cultural causes of poverty is the level of education, knowledge, customs, culture, faith, loyalty to certain views, and adherence to the model. Poverty is structurally difficult to overcome. Generally the influence of patrons (patrons), both formal, informal, or native (indigenous) to determine the success of poverty alleviation efforts of this cultural. Research in several Asian countries that the community consists of some religious groups. It shows also that the 
religious beliefs and values of society have a very significant influence on the socio-economic status of society and family. Poverty fishermen due to the differences between traditional fishing gear owned by local fishermen from outside major coastal areas should also be handled as soon as possible; from dysfunctional to functional, from the destruction of the improvements, and of the anarchist becomes persuasive. In the context of marine resource management, integrated analysis is needed to extensively provide alternatives to the utilization of marine resources which can provide benefits to local fishermen, as well as ways to achieve a resolution of poverty

According Nikijuluw (2007) itself there are five coastal community empowerment approaches. The five approaches are: (1) creation of alternative job opportunities as other sources of income for families, (2) closer to the community with a source of capital with an emphasis on creating mechanisms to fund themselves (self-financing mechanism), (3) closer to the community with a source of new technology more successful and efficient, (4) society closer to the market, and (5) build solidarity and col-

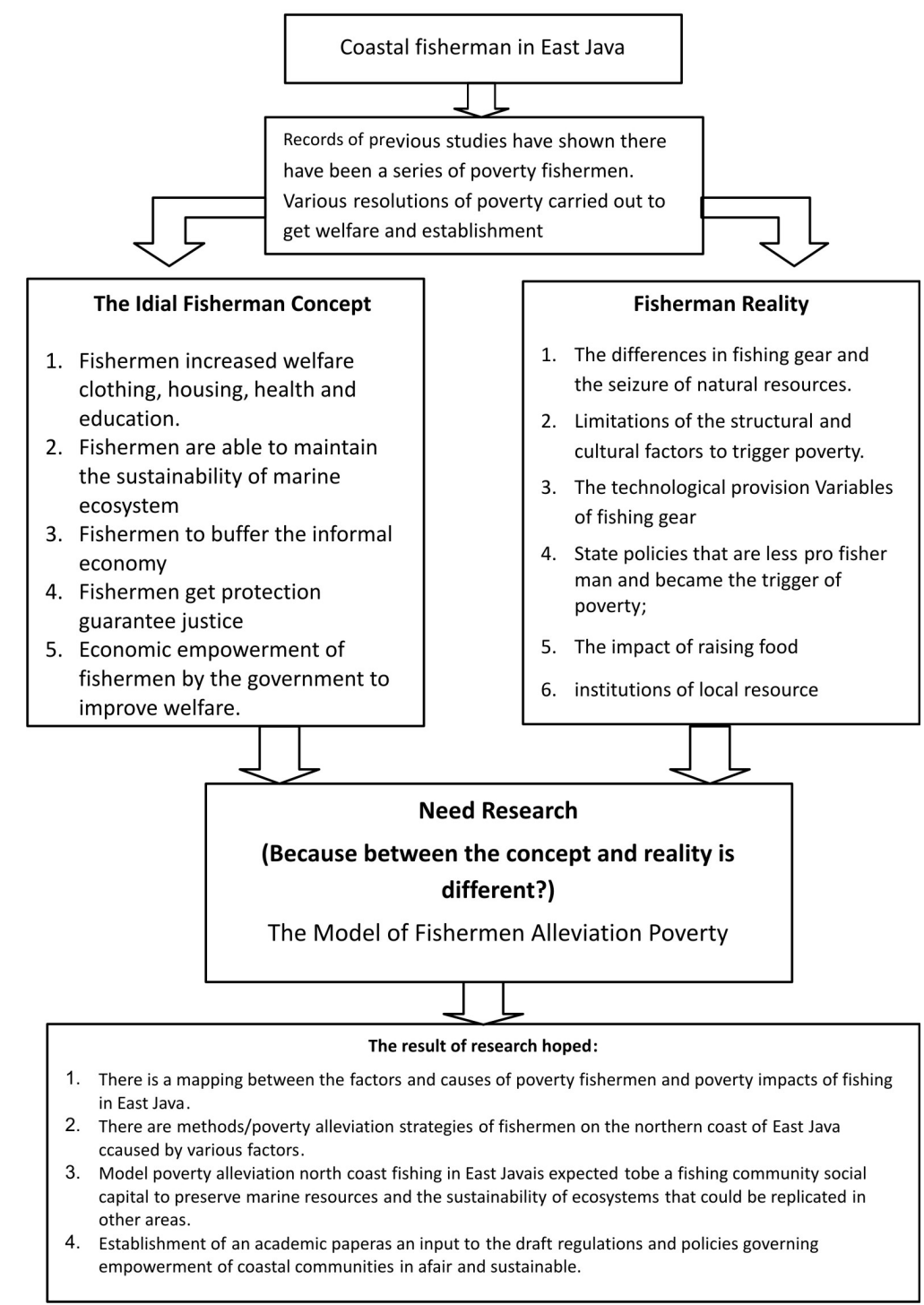

Figure 1. Conceptual Framework Research 
lective action in society. Those approach was carried out with due regard seriously the aspirations, desires, needs, income, and potential community-owned resource.

Many issues and problems in the field of marine unresolved, initiative and great ideas from Indonesia for marine sustainability and welfare of the community, creating an international conference titled "World Ocean Conference" (WOC) and the "Coral Triangle Initiative Summit (CTIS)" which held from 11 to 15 May 2009 in Manado, North Sulawesi, which was attended by representatives from 121 countries.

The main items discussed in the WOC and the CTIS are: first, the determination of seascapes (sea scapes) priority pilot large enough for proper management and sustainable for each participating country, second; development of marine conservation area networks, third; ecosystem-based fisheries management and management of living marine resources, the fourth, the development of sustainable financing, including capacity building and involvement of the private sector, fifth; measurable adjustment to climate change and the sixth, improving the status of the threat to some marine species (Ayu, 2009).

\section{RESEARCH METHOD}

The method of this study was a qualitative study into the category grounded research through Action Research approach that will explore various cases and other forms of fishing conflicts in East Java's north coast. According Muhadjir (2002) Action Research is a research model as well as practicing and theorizing or developing theories as well as implement in practice. Because this study not only satisfy the curiosity alone, but also involvement in conflict areas in terms of organizing the people and the empowerment of communities into critical success factors of this research. Approaches used to use a participatory approach, so this action research study using the method of Participatory Action Research (PAR). In the method of PAR According Huizer (1997) there are elements of the mature-oriented education in development efforts in order to empower com- munities especially those related to poverty alleviation East Java, North Coast fishermen needed by the community. Data analysis performed using the triangulation method of merging the source of the data analysis methods, data sources, the subject of research and theory.

Location of the research conducted in the northern coast of East Java in 6 areas was divided into two groups: the first group to study the first year in Gresik, Lamongan, Tuban. The second group to research the same as the continuation in the second year in Sidoarjo district, Surabaya and Probolinggo. The reason for this study choose in 6 locations/regions in the area of research because the fishermen have a uniform level of poverty.

While the subject of this research is the fishing communities who are married and belong to the poor who are unable to meet basic needs/basic and has a child or dependent expenses. The subject are both men and women and housewives. In this research will be undertaken key informants (Faisal, 1990). Key informants are expected to have enough time to spare to give information to investigators.

Besides, the other key informants who can provide data and support this research is concerned with stakeholders fisherman fishermen, among others, from Local Government, House of Representatives (DPRD), Department of Marine and Fisheries Municipality/district, Indonesian Fishermen Association (HNSI) Java East, NGOs and local fishing organizations/other regions.

Methods of data collection done by: (1) Participatory Action Research (PAR). This approach was used for observation and interview methods in a structured and profound. This section was part of the previous data collection techniques. Interviews were conducted both individually and in groups at the sites. Interviews are conducted individually or in groups that can be made in the form of small forums where participants are research subjects as described above on the subject of this research. (2) Focus Group Discussion (FGD), is one method of data collection is done through joint discussions by some of the participants by 
using a particular theme or issue as the focus (Agus Dwiyanto, 2005). The participants were representatives of various local stakeholders previously involved (both male gender and women, children and adults) who have an interest in the poverty alleviation efforts of fishermen on the north coast of East Java.

There are three aspects/activities in the analysis gerounded theory development, namely (1) write the note (2) identify the concepts (3) develop the concept and theory of constraints (Faisal, 1990). While Miles and Huberman (1992) phases of data analysis was reinforced ranging from data collection, data reduction, data presentation, and the conclusions from the data consisting later conclusion and verification of data. The steps in this analysis are, (1) Include information or collect data or records of interviews conducted to the list that have been made in the proceeding form, (2). Create a matrix of categories and placing evidence into the category of data records,(3) Explain the basic reflective concerning such records, (4) Creating the data analysis in the form of flowcharts and other devices in order to check the data, (5) Transform analysis of data from the flowchart form and schemes of a number of alternatives that allow to be used as a recommendation. Thus, the model of poverty alleviation in getting fishermen.

\section{RESULTS AND DISCUSSION}

\section{The Causes of Fishermen Poverty in East Java}

(1) The Causes of Fishermen Poverty in Gresik district. Indonesia also known as a maritime country, because based on the 1957 declaration Djoeanda sea area that reached 5.8 million square kilometers is 75 percent of the total land area of Indonesia. Conversely, land areas during the last 61 years has always been a top priority in economic development indeed only has an area of 1.9 million square kilometers or only 25 percent of the total area of Indonesia. But in reality the potential of marine resources has not been explored optimally by the nation of Indonesia. Optimizing the maritime sector will give an important contribution to Indonesia in terms of economy and technology. Value of the use of sea by the Indonesian nation is very small compared to the maritime potential. Utilization and even then still using simple methods that are less than optimal (Pranoto, 2007). Statistical data in 2005, the marine sector's contribution to gross domestic product is only Rp38.64 trillion or 2.2 percent. Not only that, the world's fisheries product trade transactions worth 70 billion dollars per year, Indonesia was only able to reap 2 billion U.S. dollars, or 2.8 percent. In

Table 1. Profile of Gresik Regency Fisherman Year 2007

\begin{tabular}{|c|c|c|c|c|c|c|c|c|}
\hline \multirow[b]{2}{*}{ Sub-district } & \multirow{2}{*}{$\begin{array}{c}\text { Results } \\
\text { Capture } \\
\text { Sea } \\
\text { (tones) }\end{array}$} & \multicolumn{3}{|c|}{ Fishing Gear (fruit) } & \multicolumn{3}{|c|}{ Seafishermen (people) } & \multirow{2}{*}{$\begin{array}{c}\text { Fishermen } \\
\text { public } \\
\text { waters }\end{array}$} \\
\hline & & $\begin{array}{c}\text { Boat } \\
\text { without } \\
\text { motor }\end{array}$ & $\begin{array}{c}\text { Boat } \\
\text { motor/ } \\
\text { outboard }\end{array}$ & $\begin{array}{c}\text { Motor } \\
\text { ship }\end{array}$ & Owner & Pendega & Andon & \\
\hline 1. Cerme & - & - & - & - & - & - & - & \\
\hline 2. Benjeng & - & - & - & - & - & - & - & \\
\hline 3. Duduk Sampeyan & - & 34 & 10 & - & 44 & - & - & 40 \\
\hline 4. Kebomas & 159,46 & 7 & 113 & - & 104 & 25 & - & - \\
\hline 5. Gresik & $2.020,83$ & 27 & 565 & - & 500 & 970 & - & - \\
\hline 6. Manyar & 176,38 & 195 & 201 & - & 465 & 74 & - & 276 \\
\hline 7. Bungah & $3.043,80$ & 72 & 700 & - & 652 & 361 & 15 & 37 \\
\hline 8. Sidayu & $1.396,48$ & 109 & 150 & - & 138 & 302 & 105 & 51 \\
\hline 9. Dukun & - & - & - & - & - & - & - & - \\
\hline 10.Panceng & 3.766 .82 & - & 609 & - & 594 & 2.110 & 150 & 10 \\
\hline 11.Ujungpangkah & $5.918,08$ & 69 & 457 & - & 482 & 1.195 & 75 & 30 \\
\hline 12.Sangkapura & $3.185,49$ & - & 602 & - & 591 & 998 & - & - \\
\hline \multirow[t]{2}{*}{ 13.Tambak } & $2.814,11$ & - & 221 & - & 210 & 466 & - & - \\
\hline & $18.714,63$ & 513 & 3.628 & & 3.780 & 6.501 & 345 & 444 \\
\hline
\end{tabular}

Source: processed from Gresik in Figures 2007 
contrast, Thailand earned 4 billion U.S. dollars and China receiving a share of around 25 billion dollars (Kompas, 27 September 2006).

Without exception in the territorial waters of Gresik save a million wealth of marine resources including marine fish that had been contested in Gresik Ujungpangkah territorial waters by fishermen from different areas such as Lamongan, Tuban, Madura, Apex Demak and other areas. Ujung pangkah waters are waters meet and flow of sea water which is the Solo river estuaries Solo stitutional role of both government and non government, the establishment of raw material (fish) that are less fair, not set anti-monopoly law, a disproportionate share of the profits who give more than the losses on the part of fishermen to benefit. Less equitable benefit sharing between the owners of fishing units and fishermen in general is due to profit-sharing system in lieu of wages for fishermen. Sharing system was implemented at nearly all small-scale fishing business.

Iniustice emerge due to a different under-

Tabel 2. The Causes of Low Fishermen Poverty in Gresik District

\begin{tabular}{clcc}
\hline No & The Causes of Low Fishermen Poverty in Gresik district & Number & $\%$ \\
\hline 1 & Law enforcement did not support the fishermen and overfished so the & 15 & 42 \\
& production is low. & 6 & 16 \\
2 & Means and infrastructure are limited & 13 & 36 \\
3 & Low education level & 2 & 6 \\
4 & Weather & 36 & 100 \\
\hline
\end{tabular}

Source: The Result of Processing data 
Meanwhile, many programs have been done by the government to tackle poverty fishermen. Programs that are common among other Presidential Instruction Program Disadvantaged Villages (IDT), the Prosperous Family Program, Infrastructure Development Program Developed Villages (P3DT), Development Program (KDP), and the Social Safety Net Programme (JPS). While the program is specifically aimed at target groups of fishing communities, among others, Coastal Community Empowerment program (PEMP) and Business Development Program Small Scale Fishing (PUPTSK).

However, in general, government programs have not made the fate of the fishermen to be better than ever. One cause of the less successful government programs in poverty reduction policy formulation fishing is top-down. Formula tends to uniform when given the problems facing fishing is very diverse and often very specific local. In addition, poverty reduction efforts of fishermen are often highly technical nature of fisheries, namely how to increase the production of the catch, while poverty must be viewed holistically as the real problems faced far more complex than that.

Other causes of poverty are no less severity is overfished in the waters of Gresik regency in the low production value caused by a reduction in fish stocks, because when the fishermen take the fish from the sea without considering the result of taking these fish cause other fishermen suffered losses due to fewer fish, on the other parties are still a lot of fishermen who use fishing gear that does not selective, the occurrence of open access in these waters, the addition of units of fishing effort and the economic exploitation that exceeds carrying capacity. Nikijuluw
(2002), states that the economic calculation of cost increases due to a decrease of fishing on marine fish stocks not only affect the fishermen who catch the fish, but also other fishermen who join exploit the fish stock. Therefore, every fisherman does not realize an increase in marginal costs due to fishing activity does, fishing as a whole tend to put too much capital or capital in the fishery. This means that externalities tend to lead to the exploitation of resources.

(2) The Causes of Fishermen Poverty in Lamongan district. The characteristics of fishermen in Lamongan average are fishermen using fishing gear Trawl. However, the availability of fishing gear/vessel trawling, which is government subsidies are found to be evenly distributed and not centralized. Besides the subsidy does not conform with the needs/designation so sold. Lamongan coastal fish stocks in the area that has begun to decrease due to the pollution of factory made tools that many do not too much work for fishermen to catch fish in waters Lamongan own, so that they then sell the trawler was in exchange for buying daily necessities that are consumptive and re-using traditional nets or other fishing gear. While the fishermen who still use the Trawl, they look for fish away from the waters of Lamongan to days so that also require significant costs as well. Broader market potential and already well known as TPI Brondong and Marine Tourism Fish Market Lamongan (WBL) should be considerable potential for fishermen to be able to develop the fishing effort and fish processing, but limited capital and expertise into a separate obstacle for them to meet the needs of market.

Based on the table above, the dominant

Tabel 3. The Causes of Fisherman Poverty in Lamongan district

\begin{tabular}{clcc}
\hline No & Causes Of Fisherman Poverty In Lamongan District & Jumlah & $\%$ \\
\hline 1 & Law enforcement did not support the fishermen and overfished so the & 1 & 3 \\
& production is low. & 2 & 6 \\
2 & Capital & 30 & 88 \\
3 & Low price & 1 & 3 \\
4 & Weather & 34 & 100 \\
& Total & & 34 \\
\hline
\end{tabular}

Source: The Result of Processing Data 
causes of poverty in Lamongan was not caused because of the low selling price. For those fishermen who use boats trawling, generally they can go to sea far from coastal waters Lamongan limiting the number of fish obtained far more than the fishermen who still use traditional fishing gear. However, the availability of ships trawling which is a government subsidy that area was not much used by fishermen in the coastal Lamongan, they still choose to use traditional fishing gear because the ship could not be used for trawl fishing around the coast but away from the waters of Lamongan to have to take some time to leave family. The catch of fish that fishermen who go to sea to get away from the Lamongan district waters causing quite a lot of fish production compared to fishermen who use traditional fishing gear. However, although there are differences in quantity of the catch, they remain low bargaining power in terms of the sale of fish. Limited capital and the urgent need to make them willing to sell his fish with a relatively low price in the skipper/baskets. "money-binding" (pesse panjher) that it is often detrimental to the fishermen, because often the money paid on the spot-or later-by the baskets to them are never the same, even lower than the real price fish if sold directly in local markets. That is, the fishermen or the skipper's head would receive the money from the purchase of fish from the basket 'is always less' than the selling price of fish in the market. The system of sales "below cost" is generally accepted or equal to all fishermen.

The other factors of poverty in Lamongan is lack of capital to develop the business. The potential market is much broader than the two other districts, were less able to be used by the fishermen to increase fish production and provide added value of processed fish. This was due to a lack of equity capital either in the form of money or skills. Besides, limited funding to develop the business are also caused by family burden is high. In addition to the cost of the lives of many fishermen is worsened by the number of children they have. In addition, the fishermen and the skipper's head had been receiving money for selling or giving part or all of the fish which is a part-according to the dealan-to the basket that had given him money. Habits give this incentive money, in many ways has become an agreement between both parties. Relations and the practice of buying and selling has become such a common pattern in almost every relationship and fish trading networks in force among traditional fishermen. The pattern of buying and selling of fish with a system of a result, fishermen are often caught by renteneer that offers loans with quick and easy, but offset by high interest rates. Capital limitation is exacerbated by the sales system that tends to be monopolized by the middlemen. As a result fishermen have no bargaining power so that the revenue earned gone to pay debts and feed. The circle of poverty is always spinning and caused marine and fisheries sector closely with poverty. The role of banking institutions in commercial lending to assist small and medium 
ineffective development. This is due to the tendency of commercial banks to fund business sectors engaged in seafood processing industry and wholesalers of marine products that have not touched on the individual fisherman. This is caused by the policies of Prudential Banking and lending requirements on the set by monetary authorities that provide a general limitation of motion for the banks to be able to reach the poor, especially poor people in coastal areas (Saleh, 2004). Furthermore, said the limitation which is quite dominant in the provision of credit to the community/economic actors in the coastal areas is a provider of security which is a condition of credit by commercial banks. Credit facilities granted to help smooth the business more productive is known as credit bank loans to help businessmen to facilitate and enhance its business activities consist of investment loans and working capital loans

The other causes of fishermen poverty that occurred in the Lamongan district is on the Regional Planning that is not on target. As in the beginning, during this time the local governments intense in providing assistance to the fishermen in Lamongan in comparison with two other districts. But according to some fishermen assistance is not centralized, so not all the fishing village to get help. In addition, local government relief is generally in the form of fishing gear/boat trawling considered one of the targets and not in accordance with the needs of fishermen, given the fact that they need is the replacement of fishing equipment whose function is not much different from the nets according to the demographic and geographic conditions of theirs, so many boats trawling of the aid is in or sold by the fishermen. In addition, the role of local governments that are less in the management of the sea yield potential and more focused on providing aid gear, making the management of fish catch less added value. The catch is that they get both from the traditional fishermen and fishing by trawl boats mostly sold without any added value at all so that the low selling price.

(3) Causes of Poverty in Tuban. The average fisherman in Tuban is not much different from the fisherman in Gresik, namely the traditional fishermen welfare state can say much than they should.

In Tuban district there are many fishermen with the pathetic condition of the house unfit for human habitation. The biggest drivers of poverty fishermen in Tuban district is a lowincome fishermen. And that became the dominant cause of the low income of fishermen due to the very limited infrastructure (Table 4). Inadequate transportation facilities, fishery harbors and TPI are not conducive and simple processing facilities are factors that support low income fishers

The other causes of fishermen poverty is due to the fishermen do not have any other skills other than as a fisherman. Although the industry has penetrated in Tuban like PT Gresik cement, but commonly the fishermen nothing is switched to the industrial sector, but because they caused less have the skills they've also caused by hereditary profession as fishermen. While job opportunities are also very limited.

So in general, the main causes of poverty in Tuban is almost the same as in Gresik, Tuban is only in the dominant factor causing the low income is due to limited facilities while working paper in Gresik caused more by the Law enforcement and overfished that eventually filled by the emergence of conflict fishermen.

\section{The Impact of Fishermen Poverty for Pantura's Society}

Poverty fishermen in the northern coast of East Java in particular area Gresik, Lamongan and Tuban in general have an impact on the lives of citizens, among others:

(1) Aspects of ecology, the use of facilities and infrastructure over fishing and didn't side law enforcement in traditional fishing as a cause of poverty lead to frequent conflicts between fishermen with fishermen because the filter catchment scramble to get the catch of fish as they expect

(2) Socio-economic and socio-cultural, poverty due to low education that makes them have no other skills to make them change the profession of traditional fishermen become fishermen working on the entrepreneur/fisherman great that they are highly dependent on the fishing 
skipper. In order to meet their needs often they owe to the owners in advance and pay with their catch at a very low price in accordance with the provisions of the skipper, (c). The emergence of paradigm in the family of fishermen that work into something far more important than continuing education. The difficulty of meeting the economic needs of low fish because the selling price, the fewer catches, and the season of uncertainty makes them more demanding members of his family in this case her children after an average junior high school do not continue to pursue higher education but rather help to fishermen or workers go fishing with other fishermen,

(3) Aspects of Health, the life of a makes heft fishermen in coastal areas and causing economic limitations in their daily lives, their lack of attention to health. housing conditions that could be considered far from decent to live is not a barrier for them to stay, so generally the shelter of coastal communities are coincide with each other and very far from saying that a healthy home,

(4) Aspects of behavior and lifestyle, economic pressure from the high does not make them to behave sparingly, otherwise they are more consumptive/wasteful when they have a little extra money or get financial aid means that any money they earned from selling fish and also from running credit business, their use for purposes that are not consumptive nature of investment

\section{Fishermen Poverty Reduction Strategy in the North Coastal Areas of East Java}

\section{(1) Fishermen Poverty Reduction Strategy in} Gresik

(a) The Low of Law Enforcement and did not side with the fishermen. The strategy needs to be done to overcome the poverty of fishing due to low Law Enforcement are: (first) it is necessary once published a social policies by the Government which contained integrated handling of poverty fishermen as they need, these policies must also be supported by policies issued by the district or city where there are poor people, especially people who work as fisher- men. The goal is to eliminate of their respective stakeholders. Integration are as follows: 1) integration in the sector responsibilities and policies. Decision addressing poverty fishermen should be taken through the process in-coordination of internal government, which need to be underlined is the poverty of fishermen will not be able to be handled institutionally by the marine and fisheries sector, but all parties involved. 2) The integration of expertise and knowledge, to formulate various policies, strategies, and programs must be supported by various scientific disciplines and expertise, the goal is to design a truly prepared in accordance with the demands of the needs of fishing communities. 3) integration problems and problem solving is necessary to know the real root causes, so that policies are made to be comprehensive and not partial. 4) integrity of location, ease of doing mentoring, counseling and services (across sectors), so the program can be done effectively and efficiently, (Second) Fishermen Institutional Development. In the initial stage, institutions that need to be developed is the Labour Group of Fishermen, which is expected to be a place for fishermen working to consolidate and actualize himself. With the number of fishermen and laborers who are very much dominant and joined in an organization will be able to improve the bargaining position of fishermen so that there is no longer owner relationship that is not mutually beneficial cooperation. The role of institutional Fisherman Group is expected as the institutional role of workers in the industrial sector with the All Indonesian Workers Union (SPSI). For fishermen who work in the fishing industry (large scale) application of the provisions of the regional minimum wage should also be applied, much less working time and risk for fishermen working harder than the workers' industry. It's time Labour Pancasila Industrial Relations system is also applied in the field of fisheries. On the other hand, given their sheer numbers, it is natural if the Government started paying attention to this Labour Fisherman Group. Can be 
ascertained that they also need guidance, and it is they who must be nurtured in order to achieve increased fishery production comes from fishing activities. The increased production will be followed by an increase in sales value of the catch and in turn will affect the income of fishermen.

In the next stage, the Group of Fishermen Workers can gradually be developed further at the Joint Business Group has the ability to invest for the conduct arrest unit together. Increased revenues can be obtained by the same mechanism with the help of units from the Government arrest, (The third) is the Control and Law Enforcement. Government through the Minister of Agriculture. No. 607 of 1975 jo. 392 of 1999 on-Line Fishing Line has sought to conflicts between fishermen mainly vertical conflicts can be avoided. In a decision is made that the fishing in the sea is divided into 3 (three) points Arrest, namely: Fishing Line I (includes coastal waters measured from sea level at low tide on each island to 6 (six) miles toward the sea ocean), Fishing Line II (including waters outside the Gaza Arrest I up to 12 nautical miles out to sea) and Line Fishing III (covering waters outside the Fishing Line II up to the outer limit ZEEI). Fishing Line I allocated for non-motorized or motorized boats with a maximum size of 5 GT, Gaza Arrest II to ship vehicles with a maximum size of $60 \mathrm{GT}$ and Line III is for motorized boats with sizes larger than $60 \mathrm{GT}$

Increased supervision and enforcement of the provisions regarding the arrest point will be able to avoid the occurrence of competition between small-scale fishermen by fishermen are more capable in the use of technology, so it gives a guarantee of the products that can be obtained by small-scale fishermen and even to avoid conflicts between fishermen due to a lane violation arrests.

In addition to the regulation, supervision and law enforcement also applies to legislation that others, including the implementation of revenue-sharing system was the implementation of the provisions of Law number 16 of 1964 concerning Fisheries Sharing. The existence of a consistent application of sanctions against the violators, it is hoped will encourage the implementation of revenue-sharing system that is more pro-labor and profitable fishing

(b) Overfishing. Too many boats chasing too Few fish "might be that terms adequately describe the sense of overfishing. regime open access is the ringleader of the occurrence of over fishing in Indonesian waters because in this regime every individual has the privileges and rights relating to the use and maintenance resources. This is a situation of reciprocal preferential treatment, no other users and weak law enforcement at sea became more and more added value over fishing in waters Indonesia. In efforts to overcome the problem of overfishing in Indonesia needed a mature strategy, one strategy is to revitalize the governance of fisheries, through the Open Access system changes to the Limited Entry or at least open Access Limited by way of emphasis on good management with a mechanism for use rights. Overfishing is not a curse that can not be lose. Political will from all parties then the problem can be overcome. Limited conception of this entry will benefit in the context of aquaculture. Not infrequently an established farming activities have collapsed because there was no certainty of law, economics and politics of spatial element. This conception can also be the starting point for the provision of clear rights to coastal fisheries fishermen to conduct its activities through the mechanism of fishing rights. In this context, the granting of fishing rights it should consider "to whom the rights granted."

\section{(2) Fishermen on the Poverty Reduction Stra- tegy Lamongan}

Poverty in coastal communities in Lamongan generally is caused of low price catches of fishermen. Capital dependence of fishermen on the skipper with the money first fastener, causing their low bargaining power, so they must accept the price set by the skipper is generally lower than prices in the market. This was done because of limited capital such as boats, fishing gear, diesel and others that they can only get from the bosses.

Besides the limited capital, the situation is 
also exacerbated by the sales system that tends to be monopolized by the middlemen. As a result fishermen have no bargaining power so that the revenue earned gone to pay debts and feed.

Solutions that can be done to improve the re-sale price for the better fisherman fish and limited capital is through several strategies, namely: Business Partnerships, Increasing Value of Fish Catch and Function Development of Microfinance Institutions

(a) Low of Sale Price. The business partnership is one of the solution to increase the income of fishermen. With the establishment of a partnership then each party interdependent and mutually benefit from business activities conducted. Partnerships are generally applied to fish farm is in the form of Nucleus-Plasma, which the Company is acting as a nucleus of Fisheries and fishermen to act as a plasma.

Under the agreement, the Company is generally obligated in the provision of core production facilities (boats, fishing gear, ice, etc.) and hold (buy) the catch of fishermen plasma. While the fishermen are catching fish obligation and sell the results to the Nucleus, with an agreed price.

With the availability of production facilities will open opportunities for fishermen unions to run their business more independently without having to depend on fishing the owner/skipper and rely on their income received from profit sharing. In contrast with the level agreed price, the sale value of the catch can be guaranteed to not decrease, so will have an effect also on the income of fishermen. In order for the agreement reached between the nucleus and the plasma can be implemented well then it is necessary to monitoring and management audits conducted by the Government. Conversely, for fishermen to manage their business well, it is necessary to aid the management of the Nucleus.

Another strategy to increase the selling price of fish, fishing is a way to increase in Value Added Fish Catch. In conducting the business of fishing, fishermen are generally oriented on the amount (volume) of the catch than the value (value) of the catch is. This led to inefficiency (waste) in the utilization of fish re- sources. One effort that can be taken to overcome these problems is to increase added value through quality coaching, among others through the use of insulated in boat/ship and use ice. With the increasing quality of the expected selling price of fish will increase, and in turn will increase the net income from fishing effort undertaken. In general, the better the quality of fish landed, then the higher price of fish per unit weight, the more so if it can meet the quality standards for export purposes. With increasing the selling value of the catch, the income of fishermen, including the income derived from profit-sharing system, will also increase.

(b) Limited Capacity. Efforts that may be done so that fishermen are not caught in the circle middlemen in overcoming the problem of capital is to develop the functions of microfinance institutions and cooperatives that sided with fishermen, other than that we need a joint effort to build a business, such as through ownership of the means of arrest and collective marketing.

\section{(3) Fishermen Poverty Reduction Strategy in Tuban}

(a) Limited Equipment. Providing assistance to the fishermen are catching unit is a step that will directly improve the income of fishermen. With the help of the income of fishermen catching unit is no longer dependent on the results obtained from the owners of the arrest, but directly from the sales value of the catch has obtained. In practice, the provision of such assistance should consider several things as follows.

First, aid is not given to individuals, but on a group of fishermen working jointly and severally. This is intended to realize the existence of a joint venture in which each member of the bear if there are losses and vice versa to obtain the same profit as if no results. Because had the same feeling it is expected that every fisherman will mean in business. In its implementation may be appointed a person who is considered able to act as a coordinator or chairman.

Second, the arrest of a given unit tailored to the wants and needs of fishermen. With the 
help of fishing units in accordance with the wishes and needs of fishermen it can be ascertained that the arrest was appropriate unit to be operated in waters where fishermen used to conduct fishing activities and does not need to mention the process for adjustments due to foreign perceived by the fishermen. Even more important, that the stronger the taste will have it so that fishing effort will be made with great earnestness. In the case want to include a new innovation, it can be done through dialogue from heart to heart with the fishermen and conducted openly.

Third, the procurement unit of the arrest to be given not through the project approach. With the approach through the project in the process from the cost side will have swollen than the real value of the units of arrest given to fishermen. The costs mainly due to the costs that must be spent in order to meet the requirements for project administration, taxes paid and benefits for executive jobs. In addition, there are inquiries from the public concerning the programs giving assistance from the Government. In general, people understand that the so-called project aid from the Government is defined as something that does not have to go back and do not have to succeed. Society becomes more intelligent and understand because of the experience gained so far.

It would be better if done with the aid delivery mechanisms through the Bank, where fishermen prospective recipient is directed to deal with the Bank where deposited funds from the Government. Psychologically fishermen will be more obedient in doing business with the Bank because it understood that the units obtained from the arrest of credit and must be returned. However, the complicated procedures that must be avoided so that no reluctant from fishermen to take care of the Bank. Terms of the guarantee to be provided by fishermen, it certainly will not ever be met by the fishermen, and therefore need to be abolished.

Fourth, the provision of assistance unit must be accompanied by the arrest of management assistance. Management assistance is needed

(b) Fisherman Living style. Stereotype as waste- ful and lazy by the various parties are often considered to be the cause poor of fishermen. Though fishing culture, if observed would have a reliable work ethic. For example, they went home at dawn the day, even at a certain time fishermen are forced to sell a couple of days at sea and catch fish at sea through the brokers who find them among the sea, then spend time on leisure time to fix the nets. There are some fishermen who have the habit and culture of extravagant and oblivious to the condition when experiencing distress.

It is necessary to attempt to change the mindset of fishermen and their families, especially regarding the ability to manage finances adjusted to normal conditions and famine, in addition to looking for alternative activities when weather conditions are uncertain. That the famine will be present in every year, therefore various strategies of adaptation done fishing communities to survive. Adaptation strategies that are usually done is to mobilize women's roles (the wife) and her children for a living. The involvement of women in earning a living for families in coastal areas or fishing villages can not be separated from the sexual division of labor system (the division of labor by sex) in effect on the local community.

Women are usually fully engaged in the activities of social and economic institutions which they form, such as gathering, teaching activities dimension of economic interest, savings and loans, and social networks they could use to support the survival of the family. The presence of these institutions is a fishing community adaptation strategies in facing life's difficulties it faces. Interpreted as an adaptation strategy choices that are rational and act effectively in accordance with the environmental context of social, political, economic and ecological, in which poor people live.

In this case the role of women fishers no longer in the realm of domestic (household) but has entered the public domain (public). In some cases, to supplement family income, the women are forced to entrust the fishermen even their small children to care for his child at an older or neighbor who does not work, because her hus- 


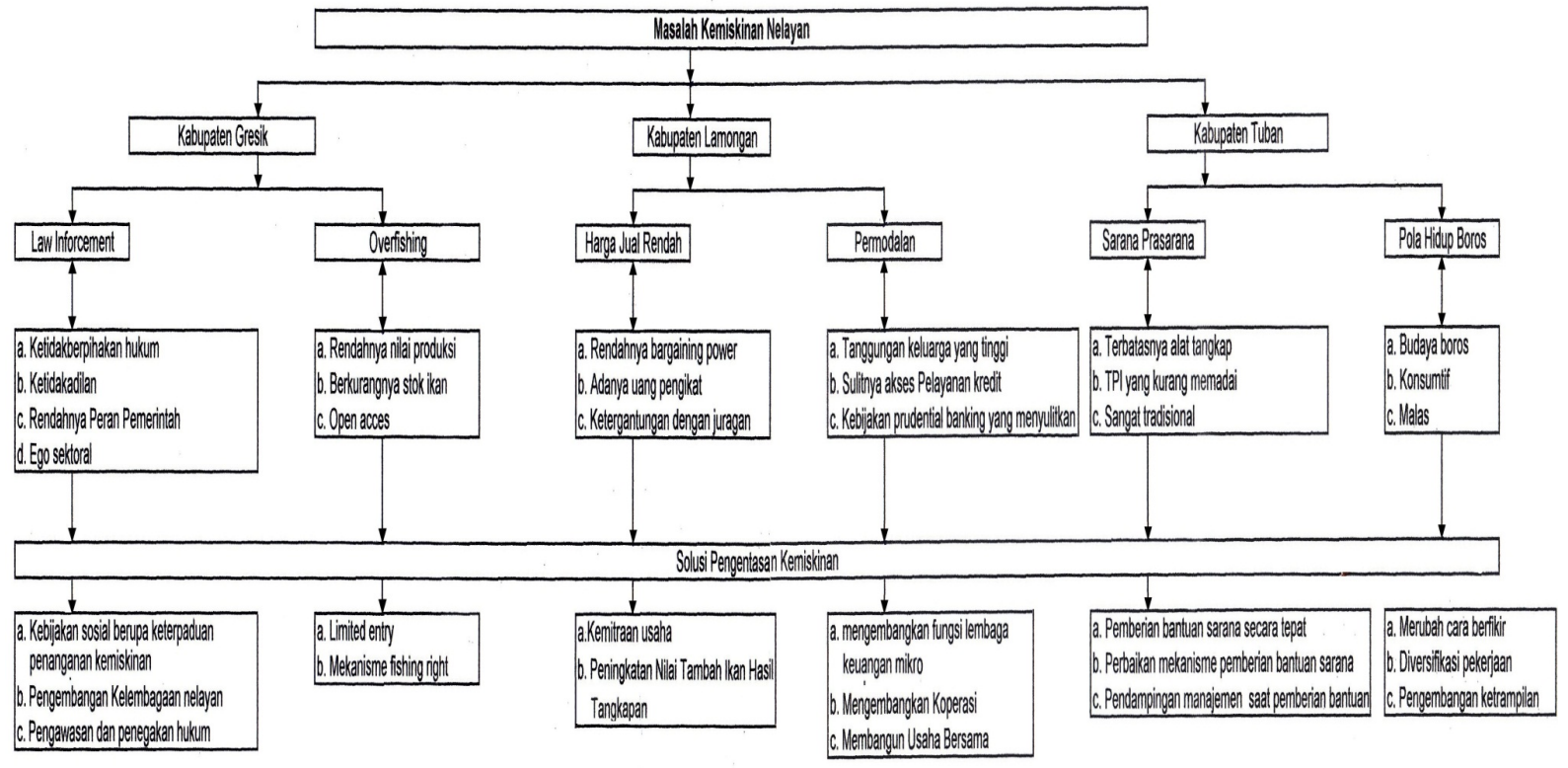

Figure 2. The Concept of Fishermen Poverty Reduction Model in the North Coastal Region of East Java

band is not living as fishermen, say teachers, traders, farmers and other others outside the profession as a fisherman. While the adaptation strategies that made the fishermen (the husband) is a diversified work to obtain new revenue sources, such as laborers in the market, carpentry and farming (for fishermen in rural areas).

Related to job verifications in an effort to improve the welfare of fishing communities, stakeholders are expected to find a good potential for regional, as well as the skill of fishing communities. This is necessary, for there are more benefit diversification, whether through the efforts of local tourism, processing of marine catches a special food, to fish farming efforts. Also need to build among stakeholders based on their capacity. For example LSM (nongovernment organization), in providing assistance and training, the government provides support for licensing and facilities and employers to provide capital assistance. With this concept, expected to famine conditions, will not be too big impact on fishing communities have been formed because the alternative jobs that are equally beneficial.
The Concept of Fishermen Poverty Reduction Model in the North Coastal Region of East Java

Furthermore, through the concept of Fisherman poverty alleviation strategies mentioned above, the model will be formulated as follows; (see Figure 2).

\section{CONCLUSION}

Poverty is a multidimensional problem that the approach to eradicate poverty must also be multidimensional. In terms of overcoming poverty of the fishermen, at least need idea and realize the hope of strengthening the maritime sector from all aspects. Starting from the gazetteer of the island, the assertion borders, strengthening the defense fleet ocean (the addition of the marine patrol boat until the ideal amount, control of fishing zones and other coastal activities, to the rescue of marine environment issues.

Thus, to overcome poverty fishermen should be preceded by the accurate statistical 
data. Further follow up on what the causes of poverty, whether because of debt bondage or other factors. Then the way or method to overcome a more focused, the fishermen who are in subordinate brokers. However also that the causes of poverty are not the same in all regions, even it may vary or depend on local conditions. So the formula can not be generalized alleviation in all regions or all sectors. Poverty experienced by the fishermen could not similar with the size of workers in urban poverty. Even in a district in the same trim size, not necessarily in the coastal villages that exist. Poverty alleviation programs fishermen need a special strategy that is able to answer the reality of that happening today. In addition, the role of the law also becomes very important for the welfare of the fishermen.

Based on the results of the study the main causes of poverty that occurred in the three districts in East Java's north coast is different from one another. In Gresik own major cause of poverty is low law Enforcement and overfishing. While in Lamongan major cause of poverty is more due to the low selling price of fish and capital problems. While the main causes of poverty that occurred in Tuban is the limited infrastructure fishermen and lazy and extravagant lifestyle of the fishermen.

Main causes of poverty difference of course leads to the solution or a different management strategies by adjusting the shortcomings and potential of each region. And it can form a concept model of poverty alleviation in their respective districts in East Java's north coast.

Recommendation. Based on the description of the subject matter of the above, then the recommendations should be made in tackling poverty fishermen are:

(1) Improving the quality of fishing communities. In this context, is the fishermen as heads of households, and fishermen as a set of families. Children fishermen are expected to complete secondary education. So that future access to maritime technological development, economic improvement is more easily done.

(2) The need to change the pattern of life of fishermen. This is related to thought patterns and habits. Consumptive lifestyles have changed for the economy slumped when fishermen are not famine. Besides saving culture in order to not get caught sharks. Also need to build eye verified special work prepared to face the famine, such as fish processing into food, the management of the beach This region with tourism and other forms of economic empowerment, so that it can increase the selling price of fish, other than just raw fish.

(3) Improving the quality of fishing equipment and marketing facilities. The need for technology support for the completeness of the boat and fishing gear, for the ability of Indonesian fishermen could be commensurate with the fishermen of other nations. Neither fish processing facilities and sales, so the selling price of fish can be improved.

(4) The need for a social policy of the government which contains a program that pro fishermen, government policy related to poverty reduction should be bottom up in accordance with the conditions, characteristics and needs of fishing communities. The policy is based upon participation or involvement of fishing communities, no longer makes the fisherman as the object of the program, but as a subject. Besides strengthening in terms of relevant laws catch zones, strengthening marine patrol fleet, and setting fishing gear that does not exploit the wealth of marine and environmental friendliness.

\section{REFERENCES}

Acheson, James M. 1981. Anthropology of Fishing. Annual Review of Anthropology. Vol 10

Andini, Ayu. 2009. Indonesia Gelar World Ocean Conference Pertama di Dunia. www.indofamilynet.com,04-05-2009 18:43

Braham, B.J. 1990. Calm Down: How to Manage Stress at Work. Illinois: Scolt, Foresman, and Co.

Dwiyanto, Agus. (Ed.). 2005. Mewujudkan Good Governance melalui Pelayanan Publik, Diskusi Kelompok Terarah dalam, Jogjakarta: Japan International Corporate 
Agency (JICA) dan Gadjah Mada University Press.

Faisal, Sanapiah. 1990. Penelitian Kualitatif: Dasar-Dasar dan Aplikasi. Malang: Yayasan Asah, Asih, dan Asuh.

Hardin, Garret dan John Baden (eds.) 1977. Managing of Common. San Fransisco: W.H. Freeman and Company.

Huizer, Gerrit. 1997. Participatory Action Research and People's Participation: Introduction and Case Studies, Third World Centre Catholic University of Nijmegen the Netherlands. Naskah dapat diakses di http://www.

fao.org/WAICENT/FAOINFO/SUSTDEV/Ppdirect/Ppre0030.htm

Iskandar, Syaifuddin, Amir Mahmud, dan Muslim. 2010. Karakteristik dan Akar Masalah Kemiskinan: Kasus Pada 4 Tipologi Desa di Kabupaten Sumbawa. Jurnal Ekonomi Pembangunan FE UMS Vol. 11 No. 1, Juni 2010. Surakarta: BPPE UMS.

Kusnadi. 2006 AkarKemiskinan Nelayan. Yogyakarta: LKIS.

Martin, Paticia Y. dan Turner, Barry A. 1986. Grounded Theory and Organizational Research.The Journal of Applied Behavioral Science, Vol. 22, Number 2, 1986 NTL Institute.

Miles, Matthew B; and Huberman, A. Michael. 1992. Analisis Data Kualitatif. Jakarta: UI Press.

Muhadjir, Noeng. 2002. Metodologi Penelitian Kualitatif, Edisi IV. Yogyakarta: Penerbit Raka Sarasin.

Nasikun. 1995.Kemiskinan di Indonesia Menurun, dalam Perangkap Kemiskinan, Problem dan
Strategi Pengentasannya. Surabaya: Airlangga University Press.

Nikijuluw, V. 2002. Rezim Pengelolaan Sumberdaya Perikanan. Jakarta: P3R dan PT. Pustaka Cidesindo.

Pruitt, D. G. dan Carnavela, P.J. 1993. Negotiation in Social Conflict, Pacific grove, CA: Brooks Cole.

Purna, Ibnu. 2004. Strategi Pengembangan Sumberdaya Perikanan dan Kelautan Berbasis Ekonomi Kerakyatan Menuju Sektor Kelautan dan Perikanan Berbasis Ekonomi Kerakyatan, Proceeding Seminar Nasional

Rapaport, A. 1974. Conflict in Man-made Environment. Harmondsworth. England: Penguin Books Ltd.

Saleh, Jamil. 2004. Strategi Pengembangan Sumberdaya Perikanan dan Kelautan Berbasis Ekonomi Kerakyatan. Peranan Sektor Perbankan dalam Upaya Pengentasan Kemiskinan dan Mendukung Kebijakan Pengentasan Kemiskinan Melalui Program Ekonomi Kerakyatan. Prosiding Seminar Nasional.

Suharsono, Yudi. 2003. Mencari Akar Psikologi Kekerasan. Jurnal Psikodinamik, Fakultas Psikologi Universitas Muhammadiyah Malang, Volume 5, Nomor 2, Juli 2003.

Suyanto, Bagong dan Karnaji. 2005. Kemiskinan dan Kesenjangan Sosial: Ketika Pembangunan tak Berpihak pada Rakyat Miskin. Surabaya: Airlangga University Press.

Wahyudi, Isa dan Muzni, Achmad Irfan.2007. Strategi Pengembangan Partisipasi Gender dalam Resolusi Konflik Nelayan Ujungpangkah Gresik, Laporan Studi Kajian Wanita Kerjasama Dikti dan LPPM Universitas Muhammadiyah Gresik. 